УДК 330

DOI: 10.35340/2308-104X.2019.84-3-12

\section{ОРГАНІЗАЦІЙНО-ЕКОНОМІЧНІ МЕХАНІЗМИ УПРАВЛІННЯ ІНФРАСТРУКТУРНИМ \\ ЗАБЕЗПЕЧЕННЯМ У БУДІВНИЦТВІ}

\author{
ORGANIZATIONAL AND \\ ECONOMIC MECHANISMS OF \\ INFRASTRUCTURAL \\ MANAGEMENT \\ MANAGEMENT IN BUILDING
}

ПРАВ Ю. Г.,

кандидат економічних наук, доцент, докторант кафедри публічного адміністрування Навчально-наукового інституту міжнародних відносин та соціальних наук ПАТ, Міждержавна академія управління персоналом
PRAV YU.,

Candidate of Economic Sciences, Associate Professor, Doctoral Student in the Department of Public Administration Educational Scientific Institute PAO International Relations and Social Sciences, Interstate Academy of Personnel Management

Визначено, щуо організаційно-економічний механізм управління в будівництві, має свої особливості та потребує більш детального вивчення його складових. Проаналізовано такі поняття, як «управління», «інвестииійно-будівельний комплекс», «система», «організаційноекономічний механізм». Виокремлено чотири рівні розвитку інфраструктури в будівництві: державний, регіональний, локальний, внутрішньофірмовий. Проаналізовано три групи видів управління: інституиійне; інформаційне. Відповідно, основними принципами побудови системи управління інфраструктурою запропоновано структуру організаційно-економічного механізму управління інфраструктурою $в$ будівниитві.

Ключові слова: організаційно-економічний механізм, управління інфраструктурою, будівництво, інвестиції.

Определено, что организационно-экономический механизм управления в строительстве, имеет свои особенности и требует более детального изучения его составляющих. Проанализировань такие понятия, как «управление», «инвестиционно-строительныи комплекс», «система», «организацийно-экономический механизм». Выделены четыре уровня развития инфраструктуры в строительстве: государственный, региональний, локальний, внутрифирмовой. Предложена структура организачийно-экономического механизма управления инфраструктурой 8 строительстве.

Ключевые слова: организационно-экономический механизм, управление инфраструктурой, строительство, инвестиции.

It is determined that the organizational and economic management mechanism in construction has its own characteristics and requires a more detailed study of its components. Analyzed such concepts as "management", "investment and construction complex", "system", "organizational and economic mechanism". Four levels of infrastructure development in 
construction were identified: state, regional, local, intra-company. The structure of the organizational and economic mechanism of infrastructure management in construction is proposed.

Key words: organizational and economic mechanism, infrastructure management, construction, investment.

Постановка проблеми. У будівництві, що характеризується складністю зв'язків між учасниками i численністю самих учасників інвестиційнобудівельного процесу, необхідно управляти інфраструктурою 3 метою більш ефективного виконання iї забезпечують функції, на всіх рівнях (державному, регіональному, локальному, внутрішньофірмовому), використовуючи як методи державного регулювання, так і саморегулювання, при цьому враховуючи іiі елементи і види. Державні установи інфраструктури представлені державними, муніципальними унітарними підприємствами та державними корпораціями, які надають послуги водопостачання, телефонії, енергопостачання, поштового та супутникового зв'язку, що виконують масштабні наукові дослідження і розробки. Розвиток i обслуговування цих напрямків інфраструктури вимагає таких фінансових витрат, що не цікаво окремим інвесторам і комерційним структурам. Крім того, не слід випускати з уваги взаємозалежність вищевказаних об'єктів інфраструктури між собою і ієрархічну структуру інфраструктурного комплексу.

Будівництво займає особливе місце в дослідженні інфраструктури. Це така сфера діяльності, яка одночасно створює основні засоби для інфраструктурних видів економічної діяльності (тому що забезпечує підприємства виробничими площами, а населення - будівлями для лікарень, шкіл і т.ін.), і в той же час сама відчуває необхідність у всіх елементах інфраструктури.

Ефективне функціонування економічної системи неможливо без іiі збалансованого забезпечення матеріальними, фінансовими, трудовими та іншими ресурсами. Концентрації великої кількості різних ресурсів в одному місці можна досягти тільки за допомогою спеціальної системи, що створює умови для цього. Такою системою є інфраструктура. Держава здійснює як пряме, так і непряме управління (стимулювання або стримування за допомогою інститутів) інвестиційно-будівельної діяльності.

Важливою частиною державного управління $\epsilon$ оцінка ефективності функціонування інфраструктури, яка повинна бути реалізовано в рамках системного підходу зі зворотним зв'язком. Ефект зворотнього зв'язку означає зворотний вплив результатів управління системою на процес цього управління або використання в управлінні інформації, що надходить від об'єкта управління. Стосовно до інфраструктури ефект зворотного зв'язку проявляється у використанні державою для раціонального управління інформації, що надходить від об'єктів їх діяльності - інфраструктури будівництва.

Аналіз останніх досліджень $і$ публікацій. Вагомий внесок у розв’язання проблем управління інфраструктурним забезпеченням в будівництві здійснили Н. М. Бондар [1], О. В. Васильєв [2], С. А. Вилгін [3], Н. І. Демчук [4], I. В. Заблодська, I. Р. Бузько, О. О. Зеленко, І. О. Хорошилова [5], В. Є. Крикавський [6] та ін.

Разом 3 тим, необхідно більш детально розглянути організаційноекономічний механізм управління інфраструктурою будівництва, який би повною мірою відображав не тільки економічні, а й організаційні аспекти управління 
інфраструктурою.

Мета статті полягає у визначенні та удосконаленні організаційноекономічних механізмів управління інфраструктурним забезпеченням у будівництві.

Виклад основного матеріалу дослідження. Організаційно-економічний механізм управління в будівництві, має свої особливості та потребує більш детального вивчення його складових. Так, з наукової точки зору управління - це спрямована координація та організація об’єкту управління. Це сфера людської діяльності, яка виникла в результаті розподілу праці, з допомогою якої людина впливає на технологічні, економічні і соціальні процеси для досягнення певних цілей.

Управління - це процес, що забезпечує (з використання за цільовим призначенням) необхідне проходження процесів перетворення енергії, речовини та інформації, підтримання працездатності та безаварійності функціонування об'єкту шляхом збирання і обробки інформації про стан об'єкту та зовнішнього середовища, вироблення рішень про вплив на об’єкт і їх використання.

Об'єктами управління в будівництві є:

виробнича діяльність будівельно-монтажних та інших організацій галузі в цілому і їх підрозділів;

реалізація проектів і програм з будівництва, технічного переозброєння, реконструкції підприємств, районів житлової забудови і т.ін .;

процеси зведення або реконструкції окремих будівельних об'єктів.

Оскільки перераховані вище об'єкти управління в будівництві мають певну територіальну прив'язку, сам процес управління може бути в повній мірі реалізований тільки на рівні регіону.

Сукупність продуктивних сил і виробничих відносин будівництва в регіоні прийнято позначати інвестиційно-будівельним комплексом (ІБК). ІБК - один 3 найбільш складних і значущих комплексів в життедіяльності будь-якого місто (регіону). ІБК представляє собою складне системне утворення, в якому виділяються два великих взаємопов'язаних базових елемента - будівництво та інвестиційна сфера, а також ієрархічно побудована послідовність інших елементів.

На наш погляд, ІБК є відкритою системщю організацій, зайнятих зведенням нових, а також реконструкцією та розширенням діючих будівель і споруд виробничого та невиробничого призначення; забезпечують будівельні процеси ресурсами і послугами; виконують науково-дослідні, проектно-вишукувальні та дослідно-конструкторські роботи і готують кадри. До складу ІБК входять як виробничі, так і невиробничі організації: громадські союзи і асоціації, вищі навчальні заклади, проектні та дослідницькі організації, ріелтерські, страхові та інвестиційні структури.

Інфраструктура також розглядається як системне поняття. У зв'язку з цим слід визначитися 3 поняттями «система» та розглянути види організації систем i їх відповідність сучасному стану ІБК в нашій країні. Поняття «інфраструктура», за визначенням С. Мочерного, це «... сукупність різних установ та інститутів, певних видів діяльності, які забезпечують рух об'єктів власності: банки, фондові й товарні біржі, біржі робочої сили, валютні біржі, інформаційні центри тощо» [7].

Система - тільки та сукупність вибірково залучених елементів, у яких 
взаємодія та взаємовідносини набувають характеру взаємосприяння діяльності елементів на отримання визначеного корисного результату (мети або цілей функціонування системи [1].

Саме, як «систему інституцій (структур), що забезпечують безпосереднє здійснення обмінних процесів, як фізичне місце контактування, взаємодії ринкових контрагентів, операторів ринку, тобто покупців та продавців. Де основними формами фізичної ринкової інфраструктури виступають біржі, оптові ринки, аукціони, ярмарки, торгові доми, міські ринки, магазини дрібнооптової та роздрібної торгівлі», Б. Губський визначає ринкову інфраструктуру [8, с. 5].

Таким чином, будівельний комплекс охоплює всі організації та підприємства, так чи інакше беруть участь у випуску будівельної продукції або забезпечують нормальний процес капітального будівництва. ІБК, поряд 3 внутрішньогалузевими зв'язками, враховує наявність міжгалузевих зв'язків, що виникають при створенні основних фондів як виробничого, так і невиробничого призначення.

ІБК також характеризується поєднанням різних функцій його суб'єктами. Так, інвестор може виконувати функції замовника (забудовника), функції генпідрядника і навіть експлуатаційні функції. Спеціалізовані будівельні організації можуть виступати в ролі субпідрядників або укладати прямі договори з інвесторами (замовниками).

Будівельні організації в даний час прагнуть до розширення своєї спеціалізації. Розвиток ринкових відносин, розширення господарської самостійності організацій призвели до того, що вони можуть займатися в установленому порядку будь-яким видом діяльності, не забороненої законами. Тому в даний час практично не залишилося організацій, які можна було б безпомилково віднести до одного виду діяльності.

На наш погляд, організаційно-економічний механізм є одним 3 етапів управління i орієнтований на підвищення продуктивності i ефективності виробництва при постійній адаптації діяльності підприємства в цілому до зміни кон'юнктури ринку і поведінки всіх його учасників. Пропонуючи в дослідженні організаційно-економічний механізм управління інфраструктурою в будівництві, ми виходили з того, що він повинен відповідати наступним вимогам:

відображати організацію і регулювання проектно-вишукувальної, будівельної, комерційної діяльності в будівництва;

забезпечувати мінімізацію часових і фінансових витрат.

Для розробки ефективного організаційно-економічного механізму системи управління інфраструктурою в будівництві, крім визначення вихідного i завершального явища, необхідно, на наш погляд, зробити класифікацію інфраструктури будівництва.

Пропонується розглянути інфраструктуру будівництва за такими видами: виробнича, соціальна та інституціональна.

Виробнича інфраструктура будівництва являє собою багаторівневу макросистему, що складається з безлічі елементів, до яких відносяться окремі підприємства і організації, що виробляють матеріали, напівфабрикати, вироби, конструкції або надають певні виробничо-технічні послуги (транспортування матеріалів, розробка проектної і робочої документації, проведення досліджень і екологічного моніторингу тощо). 
Соціальна інфраструктура являє собою сукупність установ, підприємств, об’єктів виробничої та невиробничої сфер господарства, які виконують специфічні суспільні функції, безпосередньо спрямовані на задоволення особистих матеріальних i духовних потреб людей 3 метою підвищення їх життєвого рівня [4], [9]. Іншими словами соціальна інфраструктура націлена на підтримку і підвищення рівня життя населення, а працездатне населення складає основу продуктивних сил.

Таким чином, соціальна інфраструктура, також як i виробнича інфраструктура, впливає на виробничий потенціал.

Так як інфраструктура проявляє себе як на мікро-, так і на маркоуровне, то можна виділити чотири рівні розвитку інфраструктури в будівництві: державний, регіональний, локальний, внутрішньофірмовий.

На вищому ієрархічному рівні будівельного комплексу розташовуються об'єкти виробничої та інституційної інфраструктури державного рівня магістральні трубопроводи, шляхопроводи; великі оптові бази, заводи, кар'єри, ринки інфраструктурних послуг державного значення (ринок нерудних будівельних матеріалів, ринок цементу), а також інститути саморегулювання, територіального планування, державних кошторисних норм, державних одиничних розцінок, банкрутства та ін.).

Регіональний рівень, інфраструктури представлений такими елементами виробничої та інституційної інфраструктури - міська транспортна система, системи водопостачання та каналізації, заводи, склади, оптові бази міського значення, ринок інфраструктурних послуг міського значення (транспортнологістичні компанії, оптові бази будівельних матеріалів), інститути містобудівного зонування i планування, територіальним-них кошторисних нормативів, оподаткування та ін.) [1], [8].

Нижче рівнем розташовуються виробничі та інституційні об'єкти локальної інфраструктури. Наприклад, інфраструктура окремо взятої будівництва - це організації, які надають різні супутні будівництву послуги (компанії, які надають логістичні послуги, послуги зв'язку, послуги виробничо-екологічного моніторингу, технічного нагляду тощо), інститути виробництва, реалізації, відтворення.

Є ще один рівень інфраструктури - внутрішньофірмовий. До нього відносяться невеликі підсобні визобництва і допоміжні служби фірми: ремонтномеханічні майстерні, цехи, растворо-бетонні вузли та заводи, асфальтобетонні заводи і т.ін. Окремі ділянки і бригади обслуговуються невеликими групами, ланками або декількома робочими допоміжних служб низових організацій.

Дослідники в галузі управління організаційними системами виділяють три групи видів управління [2], [5]: примушує);

1. Інституційне (адміністративне, командне, що обмежує, що

2. Мотиваційне управління (що спонукає керованих суб'єктів до вчинення необхідних дій);

3. Інформаційне управління (переконує, що грунтується на повідомленні інформації та формуванні переконань, уявлень і мотивів). 
Відповідно, основними принципами побудови системи управління інфраструктурою, вважаємо системність, ієрархічність, поєднання елементів державного управління і саморегулювання, гнучкість. На рис. 1 запропонований організаційно-економічний механізм управління інфраструктурою в будівництві.

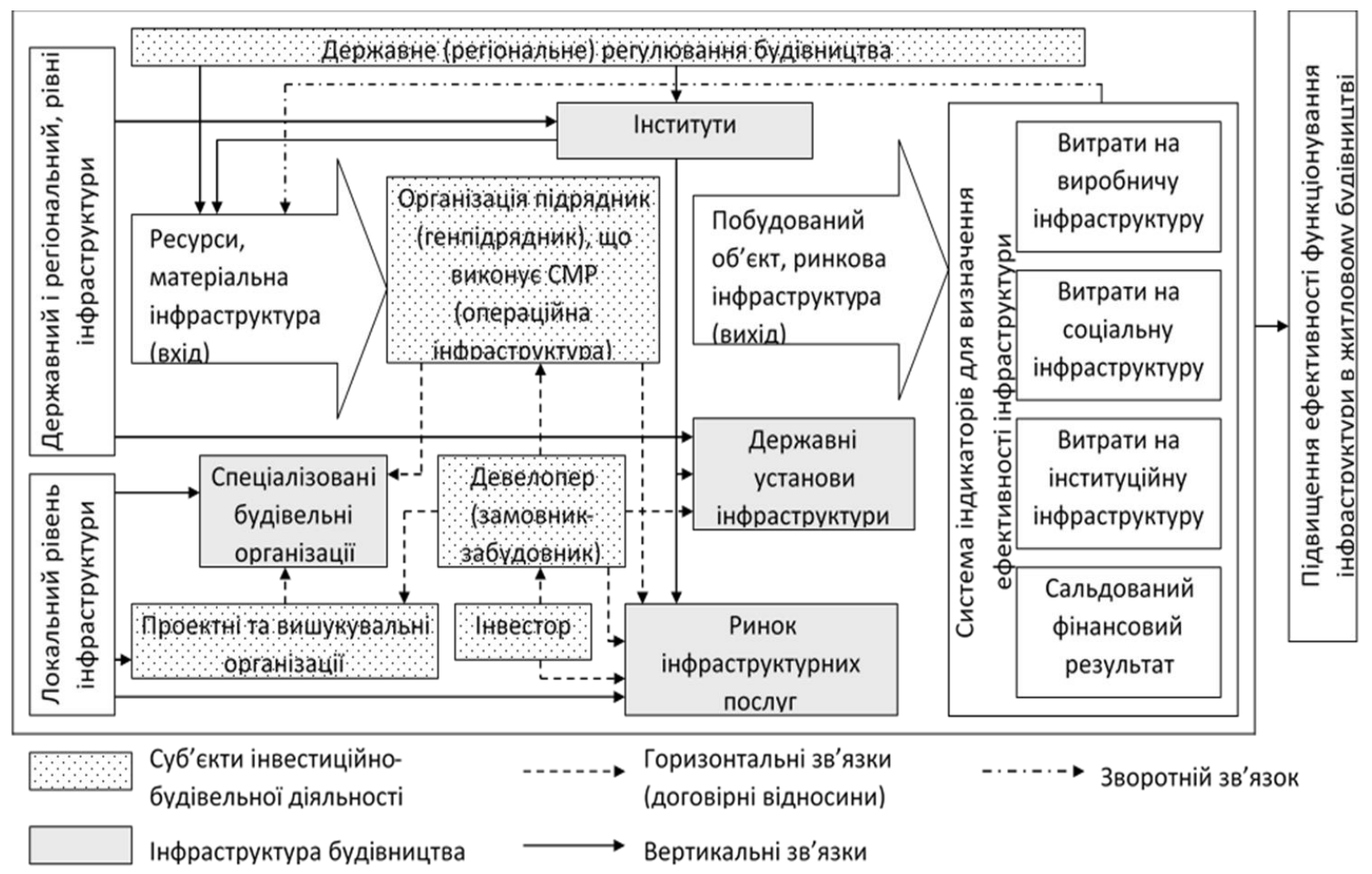

Рис 1. Організаційно-економічний механізм управління інфраструктурою в будівництві

Запропонований механізм розроблений в рамках системного підходу до інфраструктури з урахуванням розглянутих раніше особливостей інфраструктури як економічної категорії. До суб'єктів інвестиційно-будівельної діяльності віднесені девелопер (замовник-забудовник), інвестор, проектні організації, організація-підрядник. Об'єкти інфраструктури розділені на наступні блоки: інститути; спеціалізовані будівельні організації; державні установи, що надають інфраструктурні послуги; організації аутсорсингу.

Підрядні організації не можуть бути однозначно віднесені до структурних елементів ІБК або ж до інфраструктури. 3 одного боку, організація субпідрядник, що виконує основні будівельно-монтажні роботи (БМР) на майданчику $\epsilon$ структурною ланкою і ніяк не може бути віднесена до інфраструктури. У той же час супутні спеціальні роботи (виробничо-екологічний моніторинг, влаштування внутрішніх i зовнішніх інженерних комунікацій, благоустрій території, будівельний контролю і т.д.) є етапами будівництва будівлі, тобто частиною системи i, по суті своїй, утилітарні, тобто націлені на задоволення певної потреби.

Таким чином, виконуються дві ключові ознаки інфраструктурної діяльності - системність і утилітарність і тому організації, які виконують вищезазначені види робіт можна віднести і до інфраструктури.

Висновки та перспективи подальших досліджень. Визначено, що організаційно-економічний механізм управління в будівництві, має свої 
особливості та потребує більш детального вивчення його складових.

У статті пропонується організаційно-економічний механізм формування системи управління інфраструктурою, який, на відміну від раніше існуючих, включає рівні розвитку інфраструктури, їі елементи, процеси взаємодії суб'єктів, що беруть участь в інвестиційно-будівельній діяльності, вихідні та завершальні явища, що дає більш повне і об'єктивне уявлення про роль інфраструктури в будівництві.

Проаналізовано три групи видів управління: інституційне; інформаційне. Відповідно, основними принципами побудови системи управління інфраструктурою запропоновано структуру організаційно-економічного механізму управління інфраструктурою в будівництві. Запропонований механізм розроблений в рамках системного підходу до інфраструктури з урахуванням розглянутих раніше особливостей інфраструктури як економічної категорії.

Визначено, що підрядні організації не можуть бути однозначно віднесені до структурних елементів ІБК або ж до інфраструктури. 3 одного боку, організація субпідрядник, що виконує основні будівельно-монтажні роботи (БМР) на майданчику $\epsilon$ структурною ланкою $\mathrm{i}$ ніяк не може бути віднесена до інфраструктури. У той же час супутні спеціальні роботи (виробничо-екологічний моніторинг, влаштування внутрішніх і зовнішніх інженерних комунікацій, благоустрій території, будівельний контролю і т.д.) є етапами будівництва будівлі, тобто частиною системи i, по суті своїй, націлені на задоволення певної потреби. Таким чином, виконуються дві ключові ознаки інфраструктурної діяльності системність і утилітарність і тому організації, які виконують вищезазначені види робіт можна віднести і до інфраструктури.

\section{Лimepamypa:}

1. Бондар Н. М. Розвиток транспортної інфраструктури України на засадах державно-приватного партнерства: монографія. К.: НТУ, 2014. 336 с.

2. Васильєв О.В. Методологія i практика інфраструктурного забезпечення функціонування і розвитку регіонів України: монографія. Харків: ХНАМГ, 2007. 341.

3. Вилгін С. А. Розвиток інвестиційної інфраструктури у будівельному комплексі. Інвестиціï: практика та досвід. № 17. 2018. С. 74-77.

4. Демчук Н. І. Сутність соціальної інфраструктури держави в контексті регулювання транспортної галузі України. Приазовський економічний вісник. Вип. 5. 2017. C. 58-61.

5. Інфраструктурне забезпечення розвитку транспортної системи регіону: колект. монографія / за заг. ред. І. В. Заблодська, I. Р. Бузько, О. О. Зеленко, І. О. Хорошилова. Сєвєродонецьк: Вид-во СНУ ім. В. Даля, 2016. 193 c.

6. Крикавський В. Є. Державне регулювання інвестицій у логістичну інфраструктуру. Економіка і суспільство. Вип. 9. 2017. С. 253-259.

7. Мочерний С. В. Економічна теорія: Посіб. К.: ВЦ «Академія», 2003. $656 \mathrm{c}$.

8. Губський Б. В. Аграрний ринок. К.: Нора-прінт, 1998. 184 с. 


\section{References:}

1. Bondar N. M. Rozvytok transportnoji infrastruktury Ukrajiny na zasadakh derzhavno-pryvatnogho partnerstva: monoghrafija. K.: NTU, 2014. 336 s.

2. Vasyljjev O. V. Metodologhija i praktyka infrastrukturnogho zabezpechennja funkcionuvannja i rozvytku reghioniv Ukrajiny: monoghrafija. Kharkiv: KhNAMGh, 2007. 341 s.

3. Vylghin Je. A. Rozvytok investycijnoji infrastruktury u budiveljnomu kompleksi. Investyciji: praktyka ta dosvid. \# 17. 2018. S. 74-77.

4. Demchuk N. I. Sutnistj socialjnoji infrastruktury derzhavy v konteksti reghuljuvannja transportnoji ghaluzi Ukrajiny. Pryazovsjkyj ekonomichnyj visnyk. Vyp. 5. 2017. S. 58-61.

5. Infrastrukturne zabezpechennja rozvytku transportnoji systemy reghionu: kolekt. monoghrafija / za zagh. red. I. V. Zablodsjka, I. R. Buzjko, O. O. Zelenko, I. O. Khoroshylova. Sjevjerodonecjk: Vyd-vo SNU im. V. Dalja, 2016. 193 s.

6. Krykavsjkyj V. Je. Derzhavne reghuljuvannja investycij u loghistychnu infrastrukturu. Ekonomika i suspiljstvo. Vyp. 9. 2017. S. 253-259.

7. Mochernyj S. V. Ekonomichna teorija: Posib. K.: VC «Akademija», 2003. $656 \mathrm{~s}$.

8. $\quad$ Ghubsjkyj B. V. Aghrarnyj rynok. K.: Nora-print, 1998. 184 s.

It is determined that the organizational and economic mechanism of management in construction has its own peculiarities and requires a more detailed study of its components. Concepts such as "management", "investment and construction complex", "system", "organizational and economic mechanism" are analyzed. The construction infrastructure is considered in the following types: industrial, social and institutional. Four levels of development of infrastructure in construction are distinguished: state, regional, local, intra-company. Accordingly, the basic principles of the construction of the infrastructure management system are the structure of the organizational and economic mechanism of infrastructure management in construction. The proposed mechanism is developed within the framework of a systematic approach to infrastructure, taking into account previously considered features of infrastructure as an economic category. The subjects of investment and construction activity include developer (customer-builder), investor, project organizations, contractor organization. Infrastructure objects are divided into the following blocks: Institutes; specialized building organizations; state institutions providing infrastructure services; outsourcing organizations. It is determined that contracting entities cannot be uniquely assigned to the structural elements of the IBK or to the infrastructure. On the one hand, a subcontractor organization performing basic construction and installation work (BIS) at a site is a structural link and cannot be attributed to infrastructure. At the same time related special works (production-environmental monitoring, arrangement of internal and external engineering communications, improvement of the territory, construction control, etc.) are the stages of construction of the building, ie part of the system and, in essence, aimed at meeting a specific need. Thus, there are two key features of infrastructure activity - systematic and utilitarian and therefore organizations that perform the above types of work can be attributed to infrastructure. 